\title{
PENDEKATAN HOLISTIK MELALUI TINDAKAN STEREOTIP SEBAGAI DUKUNGAN ATAS ANTROPOLOGI HUKUM
}

\author{
Nama Mahasiswa : Satria Inzaghi \\ Email : satriainzaghii@gmail.com \\ No BP: 2110003600141 \\ Perguruan Tinggi : Universitas Eka Sakti Padang
}

\section{BAB I}

\section{PENDAHULUAN}

\subsection{LATAR BELAKANG}

Secara arti kata kata, istilah antropologi berasal dari bahasa Yunani, yaitu dari asal kata anthropos yang artinya manusia dan logos /logi yang artinya ilmu. Kemudian ditulis dalam ejaan bahasa Inggris menjadi Anthroplogy. Sedangkan untuk ejaan dalam bahasa Indonesia menjadi Antroplogi. Jadi kalau dalam bahasa Indonesia terdiri dari Antro artinya manusia dan logo/logi artinya ilmu. Maka sepintas dari arti kata secata etimologi dapat dikatakan bahwa antroplogi adalah ilmu yang mempelajari tentang manusia. Sehingga dapat difahami bahwa ilmu ini memfokuskan kajianaya terhadap manusia dalam arti manusia yang seutuhnya. Yaitu manusia dari aspek bentuk fisik, manusia dari aspek ruhaniah, manusia dari aspek nilai atau pikran/ide (budaya) dan manusia dari aspek tindakan, baik tindakan yang bersifat individual maupun tindakan yang berkaitan dengan orang lain dan lingkungan sekitarnya (sosial). Kajian antroplogi pada manusia ditujukan pada aspek fisik atau manusia sebgai mahluk biologi dan aspek budaya atau manusia sebagai mahluk sosial budaya.

Antropologi hukum pada dasarnya mempelajari hubungan timbal balik antara hukum dan fenomena-fenomena sosial secara empiris dalam kehidupan masyarakat ; bagaimana hukum 
berfungsi dalam kehidupan masyarakat, atau bagaimana hukum bekerja sebagai alat pengendalian sosial (social control) atau sarana untuk menjaga keteraturan sosial (social order) dalam masyarakat. Dengan kata lain, studi-studi antropologis mengenai hukum memberi perhatian pada segi-segi kebudayaan manusia yang berkaitan dengan fenomena hukum dalam fungsinya sebagai sarana untuk menjaga keteraturan sosial atau alat pengendalian sosial dalam masyarakat. Karena itu, studi antropologis mengenai hukum secara khusus mempelajari prosesproses sosial di mana pengaturan mengenai hak dan kewajiban warga masyarakat diciptakan, dirobah, dimanipulasi, diinterpretasi, dan diimplementasikan oleh warga masyarakat (F. von Benda-Beckmann, 1979, 1986).

Stereotip adalah konsepsi sifat dari prasangka subjektif. Kamus Besar Bahasa Indonesia $(K B B I)$ mengartikan stereotip adalah berbentuk tetap atau berbentuk klise. Lebih dalam, stereotip adalah konsepsi mengenai sifat suatu golongan berdasarkan prasangka yang subjektif dan tidak tetap. Apabila disederhanakan, stereotip adalah pandangan tetap pada suatu kelompok atau golongan. Inilah yang menjadikan stereotip adalah bentuk penilaian yang tidak seimbang atau tidak objektif. Munculnya stereotip adalah dipengarui kecenderungan untuk melakukan generalisasi tanpa diferensiasi.

Jalan pintas pemikiran merupakan makna lain dari stereotip atau stereotype. Stereotip adalah memiliki arah pandang negatif dan positif, bergantung pada kecenderungan orang yang memandang sesuatu. Akan tetapi, sebagian besar beranganggapan bahwa segala bentuk stereotip adalah negative dan bahkan terkadang dijadikan alasan untuk melakukan tindakan diskriminatif. Padahal tidak semua stereotip memiliki arah pandang yang negatif, terdapat juga stereotip yang memiliki arah pandang positif. Berdasarkan pandangan inilah penulis tertarik untuk mengungkap tindakan-tindakan stereotip ini sebagai dukungan atas 
Antropologi Hukum melalui pendekatan holistik yaitu keseluruhan atau keterkaitan diantara bagian-bagiannya, yang mana disini keterkaitan tersebut yaitu pada hukum dan kebudayaan. Dimana tindakan tindakan stereotip tersebut dapat dijadikan sebagai dukungan atas antropologi hukum.

\subsection{RUMUSAN MASALAH}

Rumusan masalah dalam makalah ini adalah sebagai berikut :

1. Apakah pengertian antropologi hukum?

2. Apakah pengertian peran atau peranan dalam ilmu antropologi hukum?

3. Apakah pengertian nilai dan norma dalam ilmu antropologi hukum?

4. Apakah pengertian budaya atau kebudayaan dalam ilmu antropologi hukum?

5. Apakah hubungan hukum dan kebudayaan?

6. Bagaimana pendekatan holistik dalam bidang antropologi?

7. Bagaimana tindakan stereotip yang menjadi dukungan atas antropologi hukum?

\subsection{TUJUAN PENELITIAN}

Tujuan penelitian dalam makalah ini adalah sebagai berikut :

1. Mengetahui pengertian antropologi hukum.

2. Mengetahui pengertian peran atau peranan dalam ilmu antropologi hukum.

3. Mengetahui pengertian nilai dan norma dalam ilmu antropologi hukum.

4. Mengetahui pengertian budaya atau kebudayaan dalam ilmu antropologi hukum.

5. Mengetahui hubungan hukum dan kebudayaan.

6. Mengetahui bagaimana pendekatan holistik dalam bidang antropologi.

7. Mengetahui bagaimana tindakan stereotip yang menjadi dukungan atas antropologi hukum. 


\section{BAB II \\ PEMBAHASAN}

\subsection{PENGERTIAN ANTROPOLOGI HUKUM}

Pengertian Antropologi dapat dilihat dari dua sisi yaitu Antropologi sebagai ilmu pengetahuan artinya bahwa Antropologi merupakan kumpulan pengetahuan-pengetahuan tentang kajian masyarakat dan kebudayaan yang disusun secara sistematis atas dasar pemikiran yang logis. Pengertian Antropologi yang kedua adalah cara-cara berpikir untuk mengungkapkan realitas sosial dan budaya yang ada dalam masyarakat dengan prosedur dan teori yang dapat dipertanggungjawabkan kebenarannya secara ilmiah.

Hukum yang ditetapkan itu telah mengatur berbagai aspek dalam kehidupan manusia yang secara garis besar dibuat untuk menjaga ketertiban masyarakat umum. Para antropolog berbeda pendapat soal sistem hukum. Sebahagian berpandangan bahwa aturan hukum itu ada jika masyarakat tersebut telah terbentuk sistem kehidupan berbangsa dan bernegara, sehingga masyarakat perlu ada aturan hukum yang mengikat mereka untuk memelihara ketertiban kehidupan bernegara. Pendapat seperti ini menimbulkan parsoalan tersendiri karena seolah-olah tidak ada sistem hukum bagi masyarakat tanpa negara, atau terhadap masyarakat yang masih sederhana dalam perkembanganya kebudayaanya, baik dalam komonitas berburu, maupun beetani. Pada hal masyarakat sederhana sekaliupun telah hidup dalam suatu suasana yang tertib sesuai dengan kaidah hukum yang dipedomani.

Bronislaw Malinowski menyatakan bahwa ada suatu dasar universal yang sama antara hukum dalam masyarakat bernegara dan hukum dalam masyarakat sederhana. Sehingga secara 
komperhensip dapat difahami bahwa semua aktivitas kebudayaan berfungsi untuk memenuhi suatu rangkaian hasrat naluri dari manusia berdasar saling memberi dan saling menerima, atau prinsip reciprocity, dan diantara aspek kebudayaan yang mengatur hal seperti yang demikian termasuk di dalamnya berfungsi sebagai hukum (Koentjaraningrat, 2009:161)

\subsection{PENGERTIAN PERAN ATAU PERANAN DALAM ILMU ANTROPOLOGI HUKUM}

Peranan merupakan aspek dinamis dari kedudukan, yaitu seorang yang melaksanakan hak-hak dan kewajibannya. Artinya, apabila seseorang melaksanakan hak dan kewajibannya sesuai dengan kedudukannya, maka dia telah menjalankan suatu peranan. Suatu peranan paling tidak mencakup tiga hal berikut :

1. Peranan meliputi norma-norma yang dihubungkan dengan posisi atau tempat seseorang dalam masyarakat

2. Peranan merupakan suatu konsep perihal apa yang dapat dilakukan oleh individu dalam masyarakat sebagai organisasi.

3. Peranan juga dapat dikatakan sebagai perilaku individu yang penting bagi struktur sosial.

Peranan yang melekat pada diri seseorang harusa dibedakan dengan posisi dalam pergaulan masyarakat. Posisi seseorang dalam masyarakat (social-position) merupakan unsur statis yang menunjukkan tempat individu dalam masyarakat. Peranan lebih banyak menunjuk pada fungsi, penyesuaian diri, dan sebagai suatu proses. Jadi, seseorang menduduki suatu posisi dalam masyarakat serta menjalankan suatu peranan. 


\subsection{PENGERTIAN NILAI DAN NORMA DALAM ILMU ANTROPOLOGI HUKUM}

Nilai sosial adalah nilai yang dianut oleh suatu masyarakat, mengenai apa yang dianggap baik dan apa yang dianggap buruk oleh masyarakat. Sebagai contoh, orang menanggap menolong memiliki nilai baik, sedangkan mencuri bernilai buruk. Woods mendefinisikan nilai sosial sebagai petunjuk umum yang telah berlangsung lama, yang mengarahkan tingkah laku dan kepuasan dalam kehidupan sehari-hari.

Untuk menentukan sesuatu itu dikatakan baik atau buruk, pantas atau tidak pantas harus melalui proses menimbang. Hal ini tentu sangat dipengaruhi oleh kebudayaan yang dianut masyarakat. tak heran apabila antara masyarakat yang satu dan masyarakat yang lain terdapat perbedaan tata nilai. Contoh, masyarakat yang tinggal di perkotaan lebih menyukai persaingan karena dalam persaingan akan muncul pembaharuan-pembaharuan. Sementara pada masyarakat tradisional lebih cenderung menghindari persaingan karena dalam persaingan akan mengganggu keharmonisan dan tradisi yang turun-temurun.

Drs. Suparto mengemukakan bahwa nilai-nilai sosial memiliki fungsi umum dalam masyarakat. Di antaranya nilai-nilai dapat menyumbangkan seperangkat alat untuk mengarahkan masyarakat dalam berpikir dan bertingkah laku. Selain itu, nilai sosial juga berfungsi sebagai penentu terakhir bagi manusia dalam memenuhi peranan-peranan sosial. Nilai sosial dapat memotivasi seseorang untuk mewujudkan harapan sesuai dengan peranannya. Contohnya ketika menghadapi konflik, biasanya keputusan akan diambil berdasarkan pertimbangan nilai sosial yang lebih tinggi. Nilai sosial juga berfungsi sebagai alat solidaritas di kalangan anggota kelompok masyarakat. Dengan nilai tertentu anggota kelompok akan merasa sebagai satu kesatuan. Nilai sosial juga berfungsi sebagai alat 
pengawas (kontrol) perilaku manusia dengan daya tekan dan daya mengikat tertentu agar orang berprilaku sesuai dengan nilai yang dianutnya.

Norma dalam antropologi hukum adalah seluruh kaidah dan peraturan yang diterapkan melalui lingkungan sosialnya. Sanksi yang diterapkan oleh norma ini membedakan norma dengan produk sosial lainnya seperti budaya dan adat. Ada/ tidaknya norma diperkirakan mempunyai dampak dan pengaruh atas bagaimana seseorang berperilaku. Dalam kehidupannya, manusia sebagai mahluk sosial memiliki ketergantungan dengan manusia lainnya. Mereka hidup dalam kelompok-kelompok, baik kelompok komunal maupun kelompok materiil. Kebutuhan yang berbeda-beda, secara individu/kelompok menyebabkan benturan kepentingan. Untuk menghindari hal ini maka kelompok masyarakat membuat norma sebagai pedoman perilaku dalam menjaga keseimbangan kepentingan dalam bermasyarakat.

\subsection{PENGERTIAN BUDAYA DAN KEBUDAYAAN DALAM ILMU ANTROPOLOGI HUKUM}

Budaya atau kebudayaan berasal dari bahasa Sansekerta yaitu buddhayah, yang merupakan bentuk jamak dari buddhi (budi atau akal) diartikan sebagai hal-hal yang berkaitan dengan budi dan akal manusia. Dalam bahasa Inggris, kebudayaan disebut culture, yang berasal dari kata Latin Colere, yaitu mengolah atau mengerjakan. Bisa diartikan juga sebagai mengolah tanah atau bertani. Kata culture juga kadang diterjemahkan sebagai "kultur" dalam bahasa Indonesia. 
Kebudayaan sangat erat hubungannya dengan masyarakat. Melville J. Herskovits dan Bronislaw Malinowski mengemukakan bahwa segala sesuatu yang terdapat dalam masyarakat ditentukan oleh kebudayaan yang dimiliki oleh masyarakat itu sendiri.

Istilah untuk pendapat itu adalah Cultural-Determinism. Herskovits memandang kebudayaan sebagai sesuatu yang turun temurun dari satu generasi ke generasi yang lain, yang kemudian disebut sebagai superorganic. Menurut Andreas Eppink, kebudayaan mengandung keseluruhan pengertian, nilai, norma, ilmu pengetahuan serta keseluruhan struktur-struktur sosial, religius, dan lain-lain, tambahan lagi segala pernyataan intelektual dan artistik yang menjadi ciri khas suatu masyarakat.

Menurut Edward B. Tylor, kebudayaan merupakan keseluruhan yang kompleks, yang di dalamnya terkandung pengetahuan, kepercayaan, kesenian, moral, hukum, adat istiadat, dan kemampuan-kemampuan lain yang didapat seseorang sebagai anggota masyarakat. Sedangkan menurut Selo Soemardjan dan Soelaiman Soemardi, kebudayaan adalah sarana hasil karya, rasa, dan cipta masyarakat.

Dari berbagai definisi tersebut, dapat diperoleh pengertian mengenai kebudayaan yang mana akan mempengaruhi tingkat pengetahuan dan meliputi sistem ide atau gagasan yang terdapat dalam pikiran manusia, sehingga dalam kehidupan sehari-hari, kebudayaan itu bersifat abstrak. Sedangkan perwujudan kebudayaan adalah benda-benda yang diciptakan oleh manusia sebagai makhluk yang berbudaya, berupa perilaku dan benda-benda yang bersifat nyata, misalnya pola-pola perilaku, bahasa, peralatan hidup, organisasi sosial, religi, seni, dan lain-lain, yang kesemuanya ditujukan untuk membantu manusia dalam melangsungkan kehidupan bermasyarakat. 


\subsection{HUBUNGAN HUKUM DAN KEBUDAYAAN}

Hukum ditinjau sebagai aspek dari kebudayaan. Manusia dalam hidup bermasyarakat telah dibekali untuk berlaku dengan menjunjung tinggi nilai-nilai budaya tertentu. Nilai-nilai budaya, yang oleh orang dalam masyarakat tertentu harus dijunjung tinggi, belum tentu dianggap penting oleh warga masyarakat lain. Nilai-nilai budaya tercakup secara lebih konkret dalam norma-norma sosial, yang diajarkan kepada setiap warga masyarakat supaya dapat menjadi pedoman berlaku pada waktu melakukan berbagai peranan dalam berbagai situasi sosial.

Norma-norma sosial sebagian tergabung dalam kaitan dengan norma lain, dan menjelma sebagai pranata atau lembaga sosial yang semuanya lebih mempermudah manusia mewujudkan perilaku yang sesuai dengan tuntutan masyarakatnya atau yang sesuai dengan gambaran ideal mengenai cara hidup yang dianut dalam kelompoknya. Gambaran ideal atau desain hidup atau cetak biru, yang merupakan kebudayaan dari masyarakat itu hendak dilestarikan melalui cara hidup warga masyarakat, dan salah satu cara untuk mendorong para anggota masyarakat supaya melestarikan kebudayaan itu adalah hukum.

Contoh untuk menjelaskan hubungan hukum dan kebudayaan akan diberikan contoh mengenai hubungan kekerabatan dalam sistem kekerabatan di Bali. Menurut kebudayaan Bali, perhitungan garis keturunan adalah suatu hal yang sangat penting. Nilai utamanya adalah gagasan bahwa anak laki-laki diakui sebagai pengubung dalam garis keturunan. Hal ini menghasilkan norma sosial, yaitu seseorang mempertimbangkan garis keturunannya melalui ayah sehingga dapat dikonstruksikan (secaral konseptual) suatu garis keturunan yang berkesinambungan, yang menghubungkan para laki-laki sebagai penghubungpenghubung garis keturunan. Norma sosial mengenai garis keturunan itu berhubungan 
dengan norma sosial lainnya dalam kaitan dengan pengaturan soal-soal yang berkenaan dengan kekerabatan, seperti norma sosial bahwa seseorang istri harus mengikuti suami ke tempat tinggal kerabat dari suaminya (patrilokal), norma sosial yang lain, harta dari seorang ayah diwariskan pada anaknya yang laki-laki. Norma sosial ini semuanya bergabung menjadi suau lembaga atau pranata sosial, yaitu pranata atau lembaga keluarga. Pranata ini diikuti sebagai pedoman berlaku oleh semua anggota masyarakat, bila ada anggota masyarakat tidak mengindahkan norma sosial itu, maka ini berarti nilai budaya yang mendasarinya diingkari, dan jika pelanggaran itu sering terjadi, maka nilai budaya yang mendasarinya, lama-lama akan memudar dan terancam hilang.

Sebagian dari norma sosial itu kalau dilanggar akan memperoleh sanksi yang konkret yang dikenakan oleh petugas hukum atau wakil-wakil rakyat yang diberi wewenang untuk

itu. Sebagai contoh, ada seorang istri di Bali tidak mau mengikuti suami ke tempat tinggal kerabatnya, maka ia akan dikenakan sanksi yaitu diceraikan. Jadi sebagian dari nilai-nilai budaya yang tercermin dalam norma sosial juga dimasukkan ke dalam peraturan hukum, dan karena perlindungannya terjadi melalui proses hukum, maka usaha mencegah pelanggarannya dengan sanksi hukum, dibandingkan dengan norma sosial yang merupakan kebiasaan saja.

\subsection{PENDEKATAN HOLISTIK DALAM BIDANG ANTROPOLOGI HUKUM}

Pendekatan holistik termasuk dalam bagian disiplin akademis yang didalamnya mempelajari berbagai aspek yang ada kaitannya dengan manusia sekaligus lingkungan sosialnya, sehingga ditekankan pada penggunaan metode ilmiah dalam mempelajari manusia, untuk metode ilmiah tersebut mulai dari metode kuantitatif dan kualitatif. 
Pendekatan holistik adalah bagian daripada proses pembelajaran dengan menjadikan segala hal bercampur menjadi satu kesatuan wilayah kekuatan yang utuh sehingga membuat seseorang bisa berpikir dan menganalisis suatu hal dari berbagai sisi, bahkan dari sisi yang tidak disadarinya sekalipun.

Adapun definisi pendekatan holistik menurut para ahli, antara lain;

1. Marsh (2001), Pendekatan holistik adalah proses pembalajaran dan pemberian arti pendidikan yang dilakukan dengan upaya penghargaan dengan membentuk kolaboratif saling melengkapi bagi jawab guru kelas dan guru kelas khusus kepada para peserta didiknya.

2. Goodman (1986), Arti pendekatan holistik yakni sebuah konsepsi yang berusaha memberikan acuan tentang beragam permasalahan dalam kelompok sosial masyarakat dengan lebih bersifat spesifik serta kontekstual terhadap permasalahan yang terjadi.

Pendekatan holistik dalam bidang kajian ilmu antropologi hukum misalnya saja memahami tentang adanya berbagai bentuk pakaian, gaya rambut, dan perhiasan yang dianggap menjadi bagian dari budaya material, tetapi kesesuaian mengenakan pakaian tertentu untuk acara tertentu mencerminkan budaya non material. Persefektif tentang sesuai atau tidaknya diperlukan proses belajar bagi seseorang secara menyeluruh dalam menganal arti budaya dan unsur budaya di masyarakat setempat. Oleh karena itulah tidak dibenarkan anggapan bahwa budaya yang dimiliki lebih baik sehingga memandang rendah kebudayaan lainnya. 


\subsection{TINDAKAN STEREOTIP YANG MENJADI DUKUNGAN ATAS ANTROPOLOGI HUKUM}

Stereotip dapat diartikan sebagai penilaian terhadap seseorang yang hanya atas anggapan terhadap kelompok di mana orang tersebut dapat dikelompokkan. Stereotip sendiri bisa berupa prasangka positif dan juga negatif, dan terkadang dijadikan alasan untuk melakukan tindakan diskriminatif. Namun, sebagian besar beranganggapan bahwa segala bentuk stereotip adalah negatif.

Stereotip adalah konsepsi sifat dari prasangka subjektif. Kamus Besar Bahasa Indonesia (KBBI) mengartikan stereotip adalah berbentuk tetap atau berbentuk klise. Lebih dalam, stereotip adalah konsepsi mengenai sifat suatu golongan berdasarkan prasangka yang subjektif dan tidak tetap. Apabila disederhanakan, stereotip adalah pandangan tetap pada suatu kelompok atau golongan. Inilah yang menjadikan stereotip adalah bentuk penilaian yang tidak seimbang atau tidak objektif. Munculnya stereotip adalah dipengarui kecenderungan untuk melakukan generalisasi tanpa diferensiasi.

Jalan pintas pemikiran merupakan makna lain dari stereotip atau stereotype. Stereotip adalah memiliki arah pandang negatif dan positif, bergantung pada kecenderungan orang yang memandang sesuatu. Akan tetapi, sebagian besar beranganggapan bahwa segala bentuk stereotip adalah negative dan bahkan terkadang dijadikan alasan untuk melakukan tindakan diskriminatif. 
Contoh tindakan-tindakan stereotip yang menjadi dukungan atas Antropologi Hukum :

Untuk mengulas lebih dalam terkait dengan jenis stereotip dan contohnya di masyarakat. Berikut ini adalah bentuk prilaku yang berkembang. Dimana, (Mufid, 2010) membaginya dalam 2 kelompok besar, yaitu;

\section{Stereotip positif}

Bentuk stereotip yang dapat mendukung antropologis hukum yaitu stereotip positif. Dimana stereotip ini dimaknai sebagai munculnya asumsi yang bersifat baik kepada masyarakat atau gelongan tertentu, yang akhirnya berdampak pada terciptanya rasa tolerasi, serta integrasi sosial di masyarakat.

- $\quad$ Contoh nyata dalam pandangan stereotip positif ini bisa dilihat pada gambaran Suku Sunda yang melihat Suku Jawa sebagai seseorang yang ramah, mudah bergaul, serta mampu hidup dimanapun berada. Sehingga tak khayal atas prilaku ini memunculkan persepsi bahwa orang Jawa akan senantiasa baik di mata Suku Sunda.

- $\quad$ Stereotip Musik. Stereotip yang melekat pada masyarakat bahwa orang atau masyarakat Ambon adalah orang-orang yang pandai bernyanyi serta bermain alat musik. Hal ini karena banyak penyanyii yang muncul ke publik berasal dari Ambon, seperti Glen Fredly, Andre Hehanusa, Ade Manuhutu, Harvey Malaihollo, dan lain sebagainya yang masih banyak.

\section{Stereotip negatif}


Stereotip dengan bentuk negatif adalah persepsi atas contoh asumsi yang digambarakan dalam kejelakan terhadap kelompok, arti ras, makna suku, atau yang lainnya. Sehingga diayakini pada pandangan ini dapat mengancam adanya integrasi sosial di masyarakat. Akan tetapi stereotip negatif ini juga dapat berfungsi untuk mendukung antropologis hukum jika dapat mengambil manfaat positif nya seperti contoh dibawah.

- Aparat keamanan selalu saja bisa disuap dengan uang

Hal tersebut merupakan suatu bentuk dari proses pemikiran secara cepat, disebabkan adanya banyak peristiwa yang sama, yaitu penyuapan yang dilakukan kepada aparat keamanan, sehingga munculah stereotip yang menyebar dan dikonfirmasi oleh banyak kalangan kepada semua aparat keamanan. Banyaknya kasus korupsi menjerat wakil-wakil rakyat di lembaga pemerintahan, ini membuat stereotip masyarakat menyamakan semua tabiat para pemimpinnya pada masa sekarang. Stereotip ini berkaitan dengan hukum dimasa sekarang ini yang runcing kebawah dan tumpul keatas. Artinya keadaan hukum di Indonesia pun sering danggap masyarakat bahwa hukum dapat dibeli dan orang-orang yang memiliki jabatan tersebutlah yang menang. Lalu bagaimana dengan pancasila ke-5 kita yang berbunyi "keadilan sosial bagi seluruh rakyat indonesia" dimana letak keadilannya bagi rakyat dan bagaimana tanggapan pemerintah atas hal ini?. Inilah yang menjadi alasan mengapa ini termasuk tindakan stereotip yang mendukung antropologis hukum, yaitu agar hukum di Indonesia dapat ditegakkan kembali dengan seadil-adilnya.

- Penyanyi club malam selalu mendapatkan stereotip buruk dari masyarakat umum, termasuk orang-orang yang selama ini bekerja dengan shift malam terlebih lagi bagi perempuan. Ini berhubungan dengan aturan (hukum) dan kebudayaan yang ada di 
masyarakat yaitu perempuan alangkah lebih baiknya untuk tidak diluar rumah pada malam hari. Hal ini termasuk stereotip yang mendukung antropologis hukum karena dengan adanya stereotip ini sehingga orang orang akan lebih mematuhi aturan, nilai, norma, serta kebudayaan yang berlaku di daerah.

- $\quad$ Pedang Kaki Lima

Adanya kelompok pedagang kaki lima yang terlibat konflik terhadap pegawai ketertiban kota. Kelompok pedagang beranggapan bahwa pemerintah kota yang diwakili oleh para pegawai ketertiban selaku kelompok manusia yang pemikirannya mau menang sendiri, tanpa memihak kepada rakyat kecil. Anggapan itu ditujukan kepada semua pegawai ketertiban, meskipun di antara para pegawai itu ada orang-orang yang sehari-harinya baik hati dan penuh perasaan terhadap kesusahan pedagang kaki lima. Pejabat pemerintah yang diwakili para petugas ketertiban juga muncul stereotip kepada kelompok pedagang kaki lima, stereotip tersebut dapat berupa anggapan kepada kelompok pedagang kaki lima selaku orang-orang yang tidak mengindahkan aturan yang dibuat pemerintah.

- Stereotip Pekerjaan

Stereotip ini di beberapa tempat masih terjadi, baik secara eksplisit atau implisit. Perempuan bukan pencari nafkah utama keluarga, sehingga yang bekerja dianggap sebagai "sambilan". Selain itu, banyak pekerjaan perempuan yang dianggap tidak bermoral seperti sebagai pelayan di tempat-tempat minum, tukang pijat, atau pekerjaan yang dilakukan pada malam hari. 
- $\quad$ Stereotip Gender

Dewasa ini, masih ada stereotip seorang pemimpin yang berhasil sering kali diidentikkan dengan peran jenis kelamin laki-laki. Kenyataannya, banyak pemimpin perempuan di dunia terbukti berhasil melaksanakan tugas kepemimpinannya di berbagai bidang seperti bidang organisasi bisnis, pemerintahan, keuangan dan pendidikan.

- Stereotip Perilaku Suku Tertentu

Stereotip perilaku suku tertentu ini misalnya saja kita ambil contoh orang Madura seringkali dipandang dengan cepat tersinggung, pemarah, suka berkelahi, kasar, dan kuat. Jika orang Madura dipermalukan, akan keluar belati dengan segera membalas dendam hinaan yang diterimanya, juga menunggu sampai kesempatan datang untuk membalas dendam. 


\section{BAB III \\ PENUTUP}

Antropologi hukum pada dasarnya mempelajari hubungan timbal balik antara hukum dan fenomena-fenomena sosial secara empiris dalam kehidupan masyarakat ; bagaimana hukum berfungsi dalam kehidupan masyarakat, atau bagaimana hukum bekerja sebagai alat pengendalian sosial (social control) atau sarana untuk menjaga keteraturan sosial (social order) dalam masyarakat. Pendekatan holistik dalam bidang kajian ilmu antropologi hukum misalnya saja memahami tentang adanya berbagai bentuk pakaian, gaya rambut, dan perhiasan yang dianggap menjadi bagian dari budaya material, tetapi kesesuaian mengenakan pakaian tertentu untuk acara tertentu mencerminkan budaya non material.

Stereotip adalah memiliki arah pandang negatif dan positif, bergantung pada kecenderungan orang yang memandang sesuatu. Akan tetapi, sebagian besar beranganggapan bahwa segala bentuk stereotip adalah negative dan bahkan terkadang dijadikan alasan untuk melakukan tindakan diskriminatif. Padahal tidak semua stereotip memiliki arah pandang yang negatif, terdapat juga stereotip yang memiliki arah pandang positif. Bentuk stereotip yang dapat mendukung antropologis hukum yaitu stereotip positif. Dimana stereotip ini dimaknai sebagai munculnya asumsi yang bersifat baik kepada masyarakat atau gelongan tertentu, yang akhirnya berdampak pada terciptanya rasa tolerasi, serta integrasi sosial di masyarakat. Akan tetapi terdapat stereotip negatif yang juga dapat berfungsi untuk mendukung antropologis hukum jika dapat mengambil manfaat positif nya. Tindakan-tindakan stereotip ini dapat menjadi dukungan atas Antropologi Hukum melalui pendekatan holistik yaitu keseluruhan atau keterkaitan diantara bagian-bagiannya, yang mana disini keterkaitan tersebut yaitu pada hukum dan kebudayaan. 


\section{DAFTAR PUSTAKA}

Darmini Roza dan Laurensius Arliman S, Peran Pemerintah Daerah Di Dalam Melindungi Hak Anak Di Indonesia, Masalah-Masalah Hukum, Volume 47, Nomor 1, 2018. https://doi.org/10.14710/mmh.47.1.2018.10-21

Laurensius Arliman S, Peranan Metodologi Penelitian Hukum di Dalam Perkembangan Ilmu Hukum di Indonesia, Soumatera Law Review, Volume 1, Nomor 1, 201. http://doi.org/10.22216/soumlaw.v1i1.3346.

Laurensius Arliman S, Peran Badan Permusyawaratan Desa di Dalam Pembangunan Desa dan Pengawasan Keuangan Desa, Padjadjaran Journal of Law, Volume 4, Nomor 3, 2017. https://doi.org/10.15408/jch.v4i2.3433.

Laurensius Arliman S, Penanaman Modal Asing Di Sumatera Barat Berdasarkan UndangUndang Nomor 25 Tahun 2007 Tentang Penanaman Modal, Supremasi Hukum, Volume 1, Nomor 1, 2018. http://dx.doi.org/10.36441/hukum.v1i01.102 .

Laurensius Arliman S, Memperkuat Kearifan Lokal Untuk Menangkal Intoleransi Umat Beragama Di Indonesia, Ensiklopedia of Journal, Volume 1, Nomor 1, 2018, https://doi.org/10.33559/eoj.v1i1.18.

Laurensius Arliman S, Perkawinan Antar Negara Di Indonesia Berdasarkan Hukum Perdata Internasional, Kertha Patrika, Volume 39, Nomor 3, 2017, https://doi.org/10.24843/KP.2017.v39.i03.p03.

Laurensius Arliman S, Partisipasi Masyarakat Di Dalam Pengelolaan Uang Desa PascaUndangUndang Nomor 6 Tahun 2014 Tentang Desa, Jurnal Arena Hukum, Volume 12, Nomor 2, 2019, https://doi.org/10.21776/ub.arenahukum.2019.01202.5.

Laurensius Arliman S, Mewujudkan Penegakan Hukum Yang Baik Di Negara Hukum Indonesia, Dialogica Jurnalica, Volume 11, Nomor 1, 2019, https://doi.org/10.28932/di.v11i1.1831.

Laurensius Arliman S, Mediasi Melalui Pendekatan Mufakat Sebagai Lembaga Alternatif Penyelesaian Sengketa Untuk Mendukung Pembangunan Ekonomi Nasional, UIR Law Review, Volume 2, Nomor 2, 2018, https://doi.org/10.25299/uirlrev.2018.vol2(02).1587

Laurensius Arliman S, Peranan Filsafat Hukum Dalam Perlindungan Hak Anak Yang Berkelanjutan Sebagai Bagian Dari Hak Asasi Manusia, Doctrinal, Volume 1, Nomor 2,2016.

Laurensius Arliman S, Ni Putu Eka Dewi, Protection of Children and Women's Rights in Indonesiathrough International Regulation Ratification, Journal of Innovation, Creativity and Change Volume 15, Nomor 6, 2021.

Laurensius Arliman S, Gagalnya Perlindungan Anak Sebagai Salah Satu Bagian Dari Hak Asasi Manusia Oleh Orang Tua Ditinjau Dari Mazhab Utilitarianisme, Jurnal Yuridis, Volume 3, Nomor 2, 2016, http://dx.doi.org/10.35586/.v3i2.180.

Laurensius Arliman S, Tantangan Pendidikan Kewarganegaraan Pada Revolusi 4.0, Jurnal Ensiklopedia Sosial Review, Volume 2, Nomor 3, 2020. 